\title{
Papaya Development Model As A Competitive Local Superior Commodity
}

\author{
Reny Sukmawani ${ }^{1}$, Maman Haeruman ${ }^{2}$, Lies Sulistyowati ${ }^{3}$, Tommy Perdana ${ }^{4}$ \\ ${ }^{1}$ Universitas Muhammadiyah Sukabumi, Jalan R. Syamsudin SH, No. 50 Sukabumi, \\ telephone (0266) 218345/218342 \\ 2,3,4 Universitas Padjadjaran Bandung, Jalan R. Bandung-Sumedang km 21 Jatinangor, \\ telephone (022) 7796316 \\ e-mail: renyswani@gmail.com
}

\begin{abstract}
The aim of this research is to study the comparative advantage and papaya competitive and to design its development model by using the approach of local base agriculture development. This research uses survey method. The resulting research shows that papaya is a base commodity that has comparative advantage and competitive. The development papaya in the district of Sukabumi is quite good bases on eight superior creations. But in order to be the main sector in economic development and has a competition, the development of papaya must concern to its influence factors. In supporting papaya development as a competitive local superior commodity, it needs to be done some efforts are as follows: (1) increase a skillful worker; (2) improve business management; (3) increase papaya productivity by using technology and study papaya planted technology in specific local superior commodity; (4) develop the involvement of the business relation; (5) provide market information and information technology network; and (6) improve infrastructures.
\end{abstract}

Keywords: papaya, superior commodity, competitive, comparative

JEL Classification: Q13

\section{Model Pengembangan Pepaya Sebagai Komoditas Unggulan Lokal Yang Berdaya Saing}

\begin{abstract}
Abstrak
Penelitian bertujuan untuk mempelajari keunggulan komparatif dan kompetitif pepaya sekaligus merancang model pengembangannya melalui pendekatan pembangunan pertanian berbasis lokal. Penelitian ini menggunakan metode survei. Hasil penelitian menunjukkan bahwa pepaya merupakan komoditas basis yang memiliki keunggulan komparatif dan kompetitif. Perkembangan pepaya di Kabupaten Sukabumi cukup baik berdasarkan delapan kriteria unggul, namun demikian agar pepaya benar-benar dapat menjadi penggerak utama perkembangan ekonomi dan berdaya saing maka pengembangannya harus memperhatikan faktor-faktor yang mempengaruhinya. Pengembangan pepaya sebagai komoditas unggulan lokal berdaya saing perlu mengupayakan: (1) peningkatan keterampilan tenaga kerja; (2) perbaikan manajemen usahatani; (3) peningkatan produktivitas pepaya dengan menerapkan teknologi dan melaksanakan pengkajian teknologi budidaya pepaya spesifik lokasi; (4) penumbuhan dan pengembangan jalinan kemitraan; (5) penyediaan informasi pasar dan jaringan informasi teknologi serta (6) perbaikan infrastruktur.
\end{abstract}

Kata kunci: pepaya, komoditas unggulan, daya saing, komparatif Klasfikasi JEL: Q13

\section{Pendahuluan}

Globalisasi menciptakan tantangan-tantangan persaingan baru yang menuntut para pelaku ekonomi di Indonesia untuk bisa bersaing tak terkecuali sektor pertanian. Iklim global menuntut tiap daerah untuk mampu bersaing di dalam dan luar negeri. Hal ini berimplikasi 


\section{Jurnal Ekonomi Pembangunan, 15 (2), Desember 2014, 128-140}

kepada provinsi dan kabupaten/kota untuk melaksanakan percepatan pembangunan pertanian daerah secara terfokus melalui pengembangan kawasan dan produk andalannya.

Percepatan pembangunan ini bertujuan agar daerah tidak tertinggal dalam persaingan pasar bebas, seraya tetap memperhatikan masalah pengurangan kesenjangan dan aspek lingkungan lainnya. Karena itu seluruh pelaku ekonomi, khususnya sektor pertanian harus memiliki peran dalam mengisi pembangunan pertanian dan harus mampu bekerjasama yang berkaitan antarsektor, antarprogram, antar pelaku dan antardaerah. Oleh karena itu setiap daerah diharapkan mampu berpacu dalam pembangunan serta mengelola daerahnya dengan potensi yang dimilikinya, baik sumberdaya alam maupun sumberdaya manusia.

Kabupaten Sukabumi melalui Dinas Pertanian Tanaman Pangan telah menetapkan program peningkatan kesejahteraan petani melalui kegiatan pengembangan sentra produksi dan pengembangan kawasan unggulan baik untuk palawija, buah-buahan maupun bunga potong. Salah satu komoditas potensi unggulan di Kabupaten Sukabumi adalah pepaya. Pengembangan komoditas unggulan di Kabupaten Sukabumi baru dalam bentuk kebijakan umum pengembangan kawasannya saja dengan target untuk memperluas sentra dan produksi. Sehingga nilai tambah yang diharapkan belum dapat diperoleh petani maupun pemerintah daerah secara lebih baik. Menurut Hendayana (2003), langkah menuju efisiensi pembangunan pertanian dapat ditempuh dengan mengembangkan komoditas yang mempunyai keunggulan komparatif ditinjau dari sisi penawaran dan permintaan. Masih menurut Hendayana (2003), dari sisi penawaran, komoditas unggulan dicirikan oleh superioritas dalam pertumbuhannya pada kondisi biofisik, teknologi dan sosial ekonomi. Adapun dari sisi permintaan, komoditas unggulan dicirikan dengan kuatnya permintaan pasar baik domestik maupun internasional. Dengan demikian pembangunan pertanian harus diimbangi dengan peningkatan daya saing komoditas dalam menghadapi tantangan persaingan global. Karena seperti yang dikatakan oleh Winarno (2003), bahwa pada akhirnya hanya produk-produk yang mempunyai keung- gulan kompetitiflah yang akan mampu bersaing. Sementara untuk menghasilkan produk yang kompetitif diperlukan suatu upaya untuk menembus persaingan global.

Berdasarkan hasil studi literatur diketahui bahwa penelitian tentang komoditas unggulan sudah banyak dilakukan. Penelitianpenelitian tersebut baru sebatas pada penentuan komoditas unggulan dengan salah satu atau dua metode saja yaitu dengan menggunakan analisis LQ dan atau analisis daya saing yaitu: Saptana (2010), K, Amar Zakaria dkk (2010) dan Mukhlis Sufri (2012). Beberapa penelitian yang telah dilaporkan, sejauh ini belum banyak penelitian yang mengarah pada perancangan suatu model pengembangan komoditas unggulan lokal secara khusus. Baru ada hasil penelitian yang menyarankan bahwa salah satu strategi pengembangan komoditas unggulan adalah diperlukannya suatu model pengembangan yang efektif.

Penelitian terkait dengan pengembangan komoditas unggulan yang menghasilkan rekomendasi berupa strategi pengembangan di antaranya dilakukan oleh Sonobe, Tetsushi et al (2004). Sonobe, Tetsushi et al (2004) melakukan penelitian yang menggunakan metode deskriptif dengan analisis teknik LQ dan DRC. Fokus penelitian yang dilakukan di Cina ini adalah: (1) menganalisis sektor-sektor yang dipertimbangkan sebagai unggulan untuk menghasilkan komoditas potensial yang akan dikembangkan; (2) menganalisis efisiensi usaha dalam produksi komoditas dan daya saing; (3) merancang kebijakan pengembangan dan strategi yang memimpin untuk daya saing komoditas serta pengembangan ekonomi lokal yang terintegrasi dan berkelanjutan. Hasil penelitian menyimpulkan tentang pentingnya peningkatan mutu produk dalam meningkatkan daya saing dan adanya pasar serta keterampilan dalam memasarkan.

Sementara itu penelitian yang menghasilkan suatu model pengembangan yang mengkhususkan pada komoditas unggulan di antaranya dilakukan oleh Sulaeman (2012). Penelitian Sulaeman (2012) tentang model pengembangan aloevera berbasis kluster menyimpulkan bahwa pengembangan aloevera berbasis kluster dapat meningkatkan ekonomi wilayah dan masyarakat dengan memanfaat- 


\section{Jurnal Ekonomi Pembangunan, 15 (2), Desember 2014, 128-140}

kan keunggulan sumberdaya lokal. Di lain pihak dalam membangun model pengembangan komoditas unggulan yang berdasarkan faktor-faktor yang mempengaruhinya dengan berlandaskan pada konsep daya saing perspektif mikro (perusahaan) dan perspektif makro (nasional) belum ada yang melakukan. Tetapi tinjauan secara konseptual mikromakro daya saing dan strategi pembangunan pertanian telah dilakukan oleh Saptana (2010) dan Galanos Goerge dan Giannis Manasis (2010) yang melakukan penelitian tentang analisis daya saing dengan menggunakan model Porter's Diamond pada minyak zaitun di Yunani. Hasil penelitian pada akhirnya menyajikan saran tentang perlunya penerapan metode inovatif dan perintis serta strategi dalam rangka untuk membedakan, menambah nilai produk yang ditawarkan dan mendukung berkelanjutan pertumbuhan seluruh sektor.

Selain itu penelitian yang menghasilkan suatu model pengembangan komoditas unggulan berbasis lokal dan berdaya saing belum ada yang melakukan. Penelitian yang sudah ada baru dilakukan oleh Agus, Moch Krisno Budiyanto (2010) yang melakukan kajian berjudul "Model Pengembangan Ketahanan Pangan Berbasis Pisang melalui Revitalisasi Nilai Kearifan Lokal". Penelitian yang dilaksanakan di Kabupaten Lumajang, Malang dan Blitar ini menggunakan pendekatan kualitatif dengan desain penelitian deskriptif kualitatif di mana data yang diperoleh dianalisis dengan analisis kualitatif (Content Analysis dan Domain Analyisis). Hasil penelitian di antaranya menyimpulkan bahwa: optimalisasi peran kearifan lokal dapat dijadikan fokus utama dalam upaya mengembangkan ketahanan pangan berbasis pisang. Beberapa komponen penting dan strategis dalam model pengembangan ketahanan pangan berbasis pisang melalui revitalisasi nilai kearifan lokal dan penguatan kelembagaan kelompok tani adalah: a) kearifan lokal (penguatan penggunaan bahan pangan berbasis lokal, peran perempuan, peran tokoh masyarakat/agama, gotong royong, guyub rukun, desa mandiri pangan, pertanian ramah lingkungan, pertanian multikultur, dan perencanaan berbasis masyarakat); b) pemerintah daerah; c) peran BPTP, BBMP, DUDI (pengembangan pilot projecting, permodalan, pendampingan dan penguatan sistem produksi-distribusi-pemasaran-konsumsi).

Berangkat dari latar belakang tersebut, penelitian ini dilakukan dengan tujuan untuk mempelajari keunggulan komparatif dan kompetitif pepaya sebagai salah satu komoditas unggulan lokal Kabupaten Sukabumi serta sekaligus merancang model pengembangannya melalui pendekatan pembangunan pertanian berbasis lokal. Terbentuknya model pengembangan komoditas unggulan lokal ini, diharapkan dapat menjadi salah satu solusi untuk memperbaiki kondisi sosial ekonomi pertanian di tingkat daerah.

\section{Metode Penelitian}

Penelitian ini menggunakan metode survei. Fokus penelitian adalah mempelajari keunggulan komparatif dan kompetitif pepaya sebagai salah satu komoditas unggulan lokal Kabupaten Sukabumi, sekaligus merancang model pengembangannya melalui pendekatan pembangunan pertanian berbasis lokal. Unit analisisnya adalah petani yang melakukan usahatani pepaya, pelaku usaha kecil, menengah dan besar, instansi/lembaga, tokoh dan tenaga ahli yang terkait dengan pengembangan pepaya di Kabupaten Sukabumi.

Penelitian berupa studi kasus. Pemilihan lokasi berdasarkan pada potensi dibidang pertanian dilihat dari kondisi wilayah dan geografisnya. Kabupaten Sukabumi dengan luas wilayah terluas di Jawa dan Bali dan potensi pertanian yang cukup baik. Tetapi potensi tersebut belum dikembangkan secara maksimal. Salah satu upaya untuk memaksimalkan potensi wilayah ini di antaranya melalui pengembangan komoditas unggulan.

Teknik pengambilan sampel ditentukan berdasarkan hasil survei awal. Mengingat populasi berada di 47 Kecamatan dan karena sifat lahan/sebaran geografis serta kebiasaan petani relatif sama, maka pengambilan sampel dilakukan dengan cluster sampling. Pada Cluster sampling populasi dibagi dulu atas kelompok berdasarkan area atau cluster. Beberapa cluster dipilih dulu sebagai sampel, kemudian dipilih lagi anggota unit dari sampel cluster tersebut (Nazir, M, 2005). Pengambilan 
sampel dilakukan dua tahap, yakni pertama menentukan lokasi kecamatan dan desa. Pemilihan desa ditentukan berdasarkan petimbangan luas tanam. Kemudian pada tahap kedua, menentukan sampel petani secara acak di masing-masing desa terpilih. Sedangkan dalam penentuan sampel pedagang serta industri dilakukan secara sengaja tanpa acak (random).

\subsection{Analisis Komparatif dan Kompetitif Pepaya}

Untuk menentukan apakah pepaya ini layak dikatakan sebagai komoditas unggulan baik secara kompetitif maupun komparatif, dilakukan tiga analisis yaitu: analisis lokasi dengan metode Location Quotient (LQ), analisis kriteria unggul dan analisis daya saing dengan menggunakan pendekatan PCR serta DRCR.

(1) Analisis Location Quotient (LQ), yaitu: perbandingan antara pangsa relatif produksi komoditas i pada tingkat wilayah terhadap total produksi wilayah dengan pangsa relatif produksi komoditas i pada tingkat wilayah di atasnya terhadap total produksi wilayah tersebut.

$L Q=\frac{p i / p t}{p i / p t}$

di mana $\mathbf{p}_{\mathbf{i}}$ adalah luas lahan komoditas i di daerah yang diteliti, $\mathbf{p}_{t}$ adalah luas lahan seluruh komoditas di daerah yang diteliti, $\mathbf{P}_{\mathbf{i}}$ adalah luas lahan komoditas i di daerah lebih atasnya, $\mathbf{P}_{\mathrm{t}}$ adalah luas lahan seluruh komoditas di daerah lebih atasnya. Hasil perhitungan LQ kemudian diinterpretasi dalam tiga kriteria, yaitu: apabila LQ lebih dari 1 (satu), artinya komoditas itu menjadi basis atau sumber pertumbuhan. Komoditas memiliki keunggulan komparatif, dan hasilnya tidak saja dapat memenuhi kebutuhan di wilayah bersangkutan akan tetapi juga dapat dikirim ke luar wilayah; LQ sama dengan 1 (satu), maka komoditas ini tergolong non basis, tidak memiliki keunggulan komparatif. Produksinya hanya cukup untuk memenuhi kebutuhan wilayah sendiri; dan apabila LQ kurang dari 1 (satu), menunjukkan bahwa komoditas tidak termasuk non basis dan tidak dapat memenuhi kebutuhan sendiri sehingga perlu pasokan dari luar.

(2) Menggunakan metode description scoring melalui penilaian terhadap indikator dari tiap kriteria unggul untuk komoditas yang akan ditetapkan keunggulannya. Skoring dilakukan dengan menggunakan skala Likert.

(3) Menggunakan analisis daya saing (keunggulan komparatif dan kompetitif) melalui pendekatan PCR (Private Cost Ratio) dan DRCR (Domestic Resource Cost Ratio. Nilai PCR mencerminkan berapa banyak sistem komoditas tersebut dapat membayar input faktor domestik dan tetap dalam kondisi kompetitif, sehingga merupakan indikator keunggulan kompetitif.

$P C R=\frac{D F C_{H P}}{\left(R_{H P}-T I C_{H P}\right)}$

Keterangan:

$\mathrm{DFC}_{\mathrm{HP}}=\Sigma\left(\mathrm{X}_{\mathrm{d}} \mathrm{P}_{\mathrm{dHP}}\right) ; \mathrm{R}_{\mathrm{HS}}=\Sigma\left(\mathrm{Q}_{\mathrm{y}} \mathrm{P}_{\mathrm{yHP}}\right) ; \mathrm{TIC}_{\mathrm{HP}}=$ $\Sigma\left(\mathrm{X}_{\mathrm{t}} \mathrm{P}_{\mathrm{tHP}}\right)$

di mana PCR adalah Private Cost Ratio, DFC $_{\text {HP }}$ adalah jumlah biaya faktor domestik dengan harga private, $\mathbf{R}_{\mathrm{HP}}$ adalah jumlah penerimaan kotor dengan harga private, TICHP adalah jumlah biaya input tradable dengan harga private, $\mathbf{X d}$ adalah jumlah penggunaan faktor domestik, $\mathbf{P}_{\mathbf{d H P}}$ adalah harga private faktor domestik, $\mathbf{Q}_{\mathbf{y}}$ adalah jumlah output tradable, $\mathbf{P}_{\mathbf{y H P}}$ adalah harga private output tradable, $\mathbf{X}_{\mathbf{t}}$ adalah jumlah penggunaan input tradable dan $\mathbf{P}_{\mathbf{t H P}}$ adalah harga private input tradable. Kemudian apabila hasil analisis menunjukkan nilai PCR kurang dari 1 (satu), maka komoditas tersebut mampu membiayai input faktor domestiknya pada harga privat dan memiliki keunggulan kompetitif. Sedangkan apabila PCR lebih besar dari 1 (satu), maka komoditas tersebut tidak mampu membiayai input faktor domestiknya pada harga privat dan tidak memiliki keunggulan kompetitif.

Analisis daya saing berikutnya adalah DRCR, yaitu nisbah biaya faktor domestik dari harga sosial terhadap nilai tambah, yaitu selisih antara penerimaan kotor dan biaya input tradabel (yang semuanya didasarkan pada harga - harga bayangan / shadow prices). 


\section{Jurnal Ekonomi Pembangunan, 15 (2), Desember 2014, 128-140}

$$
\mathrm{DRCR}=\frac{D F C_{H S}}{\left(R_{H S}-T I C_{H S}\right)}
$$

Keterangan:

$\mathrm{DFC}_{\mathrm{HS}}=\Sigma\left(\mathrm{XdPdHS}_{\mathrm{H}}\right) ; \mathrm{R}_{\mathrm{HS}}=\Sigma(\mathrm{Qy} \mathrm{PyHS}) ; \mathrm{TICHS}_{\mathrm{HS}}=$ $\Sigma\left(\mathrm{XtP}_{\mathrm{tHS}}\right)$

di mana DRCR adalah Domestic Resource Cost Ratio, $\mathbf{D F C}_{\mathbf{H S}}$ adalah jumlah biaya faktor domestik dengan harga sosial, $\mathrm{R}_{\mathrm{HS}}$ adalah jumlah penerimaan kotor dengan harga sosial, TICHs adalah jumlah biaya input tradable dengan harga sosial, $\mathbf{X d}$ adalah jumlah penggunaan faktor domestik, $\mathbf{P}_{\mathbf{d H S}}$ adalah harga sosial faktor domestik, $\mathbf{Q}_{\mathbf{y}}$ adalah jumlah output tradable, $\mathbf{P}_{\mathbf{y H s}}$ adalah harga sosial output tradable, $\mathbf{X}_{\mathbf{t}}$ adalah jumlah penggunaan input tradable, dan $\mathbf{P}_{\mathrm{tHS}}$ adalah harga sosial input tradable. Apabila hasil analisis menunjukkan nilai DRCR lebih kecil dari 1 (satu), maka komoditas tersebut memiliki keunggulan komparatif, semakin efisien dan mampu hidup tanpa bantuan atau intervensi pemerintah serta mempunyai peluang untuk ekspor. Kemudian apabila nilai DRCR lebih besar dari 1 (satu), maka komoditas tersebut tidak memiliki keunggulan komparatif, tidak mampu hidup tanpa bantuan atau intervensi pemerintah. Kegiatan ini akan memboroskan sumberdaya domestik yang langka karena memproduksi komoditas dengan biaya yang lebih besar daripada baya impornya.

\subsection{Model Pengembangan Pepaya}

Langkah dari penyusunan model konseptual pada penelitian ini meliputi: (1) penentuan jenis sifat model, (2) identifikasi variabel-variabel, (3) mengklasifikasikan variabel-variabel tersebut, (4) pendefinisian variabel-variabel tersebut secara operasional dan (5) pembuatan sistem asumsi.

Sebelum model dirancang terlebih provinsi dilakukan identifikasi terhadap faktor-faktor yang dapat mempengaruhi pengembangan komoditas unggulan yang pada penelitian ini dilakukan dengan menggunakan metode SEM (Structural Equation Modeling). Sehingga dari hasil analisis SEM dapat terbangun model pengembangan pepaya sebagai komoditas unggulan yang berdaya saing. Menurut Cooper
\& Schindler (2006), secara umum prosedur SEM meliputi: spesifikasi model, estimasi, uji kecocokan, respesifikasi, interpretasi dan komunikasi.

Faktor-faktor yang mempengaruhi pengembangan pepaya pada penelitian ini didasarkan pada landasan teori yang diambil dari Porter yaitu model Porter Diamond (Porter, 1998). Terdapat empat faktor dalam model Porter Diamond yaitu kondisi faktor, kondisi permintaan, industri pendukung dan terkait, serta persaingan, struktur dan strategi perusahaan.

(1) Kondisi faktor pada pengembangan pepaya meliputi: tenaga kerja, ketersediaan sumberdaya lokal (benih/bibit, air), kecukupan modal dan dukungan infrastruktur.

(2) Kondisi permintaan akan pepaya akan diamati berdasarkan: kemampuan penjualan dan banyaknya permintaan terhadap produk.

(3) Industri pendukung dan terkait pada penelitian ini diadaptasi ke dalam dukungan kelembagaan, yaitu merupakan dukungan terhadap akses sarana dan prasarana pengembangan komoditas unggulan lokal. Dukungan ini digambarkan oleh keberadaan kelembagaan tani, akses terhadap lembaga keuangan, lembaga penyuluhan dan lembaga pemasaran.

(4) Strategi dan persaingan, meliputi kondisi yang menggambarkan kemampuan berusaha yang kompetitif. Variabel yang diamati adalah: dukungan investasi bagi petani, kebijakan pemerintah yang berkaitan dengan usaha tani (pajak, subsidi, harga).

Sementara itu kinerja pengembangan pepaya pada penelitian ini dilihat berdasarkan indikator balanced scorecard. Secara umum seseorang dikatakan berhasil dalam usahanya apabila dilihat dari tingginya keuntungan yang diraih (profitabilitas) dan semakin berkembangnya skala usaha (produktivitas dan pasar). Konsep ini dapat diterapkan pada usaha jenis apapun, baik barang maupun jasa. Demikian pula halnya dalam usaha di bidang pertanian. Pendekatan alternatif dengan rumusan yang jelas tentang apa saja yang harus diukur oleh suatu usaha dalam menyeimbangkan sudutsudut pandang dalam pelaksanaan dan pengendalian rencana-rencana strategis di antaranya terdapat dalam konsep Balanced Scorecard. 
Terdapat empat perspektif dalam balanced scorecard yaitu perspektif keuangan, produk dan pelanggan, operasional dan sumberdaya.

(1) Perspektif keuangan, pada perspektif ini variabel yang akan diamati adalah profitabilitasnya atau laba yang didapat dari usahatani pepaya. (2) Perspektif produk dan pelanggan, pada perspektif ini yang akan diamati kondisi pasar pepaya yaitu berapa jumlah penjualan setiap musim panen. (3) Perspektif operasional, yang akan diamati berdasarkan produktivitasnya atau produksi pepaya per hektar per musim. (4) Perspektif sumberdaya, yang akan amati pada perspektif ini adalah pembelajaran yakni frekuensi petani pepaya mengikuti penyuluhan dari lembaga terkait.

\section{Hasil Penelitian dan Pembahasan}

\subsection{Keunggulan Komparatif dan Kompe- titif Pepaya}

Analisis komparatif dan kompetitif pepaya dilakukan dengan tiga metode, yaitu: analisis LQ, analisis berdasarkan kriteria unggul (description scoring) dan analisis daya saing. Aplikasi metode LQ yang digunakan pada penelitian ini adalah berdasarkan data luas lahan. Penghitungan dilakukan secara sederhana, tanpa survey langsung ke lapangan, cukup menggunakan data sekunder. Namun demikian walaupun tidak turun ke lapangan tetap membutuhkan akurasi data yang tepat. Asumsi yang digunakan ketika menggunakan analisis LQ pada penelitian ini adalah:

(1) Jika produksi tinggi maka lahan sebagai tempat tumbuh tanaman dianggap layak atau sesuai dengan persyaratan tumbuh yang dikehendaki tanaman.

(2) Agar data valid, digunakan data series selama 5 tahun terakhir kemudian dirataratakan.

Berdasarkan kedua asumsi tersebut, tampak bahwa analisis LQ memerlukan analisis gabungan untuk menutupi kelemahannya. Namun, hasil LQ tetap dapat dimanfaatkan sebagai indikasi terhadap sektor basis di mana semakin besar nilai LQ di suatu wilayah semakin besar pula derajat konsentrasinya di wilayah tersebut. Di samping itu menurut Sukmawani, et al. (2014). hasil LQ merupakan indikator awal untuk menentukan posisi surplus atau defisit suatu daerah dalam hal konsumsi atau produksi tertentu.

Penetapan keunggulan pepaya dilakukan juga melalui penilaian kriteri unggul untuk melengkapi metode LQ. Kriteria yang digunakan merupakan parameter yang dianggap mewakili keunggulan bersaing dari komoditas secara kompetitif. Sehingga komoditas dengan kriteria terbaik dapat dikatakan unggul secara kompetitif. Penilaian keunggulan pepaya berikutnya adalah melalui metode analisis daya saing. Metode ini dipilih karena mencerminkan keunggulan komparatif dan kompetitif.

Hasil penelitian menunjukkan bahwa pepaya memiliki keunggulan komparatif dan kompetitif berdasarkan nilai LQ, kriteria unggul dan daya saingnya (PCR dan DRCR). Tabel 1 menunjukkan bahwa pepaya merupakan komoditas basis, memiliki keunggulan komparatif, dan hasilnya tidak saja dapat memenuhi kebutuhan di Kabupaten Sukabumi, akan tetapi juga dapat dikirim ke luar wilayah Kabupaten Sukabumi.

Nilai LQ dari pepaya adalah 4,94. Artinya produksi pepaya di Kabupaten Sukabumi tingkat konsentrasi lahannya 4,94 kali lebih tinggi. Menurut Widiatnaka dkk (2013), nilai LQ yang tinggi ini tidak mencerminkan areal lahan yang luas. Hal ini terbukti pada penelitian ini di mana luas lahan dan luas panen pepaya di Kabupaten Sukabumi sesungguhnya bukan yang paling luas bila dibandingkan beberapa tanaman lainnya yang ada di Kabupaten Sukabumi. Tetapi bila dibandingkan dengan Jawa Barat, komoditas lain yang ada di Kabupaten Sukabumi masih kalah basis. Lain halnya dengan pepaya, ketika dibandingkan di tingkat provinsi, pepaya di Kabupaten Sukabumi lebih unggul. Metode LQ dengan segala keterbatasannya dapat dijadikan landasan dalam menentukan langkahlangkah yang harus dipilih dalam rangka pertumbuhan ekonomi suatu wilayah. Menurut Amalia (2014), pengembangan metode ini penting untuk menganalisis perekonomian suatu daerah. Akan tetapi menganalisis perekonomian suatu daerah dibatasi oleh faktor-faktor penghambat seperti faktor data yang sangat terbatas di daerah. 


\section{Jurnal Ekonomi Pembangunan, 15 (2), Desember 2014, 128-140}

Tabel 1. Hasil analisis komparatif dan kompetitif Pepaya

\begin{tabular}{|c|c|c|c|}
\hline No & Metode Analisis & Nilai & Keterangan \\
\hline 1 & LQ & 4,94 & $\begin{array}{l}\text { Komoditas ini menjadi basis atau sumber pertumbuh- } \\
\text { an. Komoditas memiliki keunggulan komparatif, hasil- } \\
\text { nya tidak saja dapat memenuhi kebutuhan di wilayah } \\
\text { bersangkutan tetapi juga dapat dikirim ke luar } \\
\text { wilayah }\end{array}$ \\
\hline 2 & Kriteria unggul & 66,90 & Cukup baik \\
\hline 3 & PCR & 0,21 & $\begin{array}{l}\text { Komoditas ini mampu membiayai input faktor domes- } \\
\text { tiknya pada harga privat dan memiliki keunggulan } \\
\text { kompetitif. }\end{array}$ \\
\hline 4 & DRC & 0,23 & $\begin{array}{l}\text { Komoditas ini memiliki keunggulan komparatif, sema- } \\
\text { kin efisien dan mampu hidup tanpa bantuan atau } \\
\text { intervensi pemerintah serta mempunyai peluang } \\
\text { untuk ekspor. }\end{array}$ \\
\hline
\end{tabular}

Sumber: data primer dan data sekunder, diolah (2014)

Hasil analisis kriteria unggul pada pepaya menunjukkan bahwa nilainya adalah 66,90. Nilai ini cukup baik. Produksi pepaya di Kabupaten Sukabumi tersebar di 7 kecamatan yaitu Kecamatan Kalapanunggal, Lengkong, Cibadak, Cicurug, Cidahu, Parakansalak dan Cikidang. Perkembangan pepaya di Kabupaten Sukabumi cukup baik berdasarkan delapan kriteria unggul, namun demikian pepaya belum benar-benar dapat menjadi penggerak utama perkembangan ekonomi walaupun layak secara ekonomi. Di sisi lain, pepaya juga dianggap dapat bertahan dalam jangka waktu panjang dan tidak rentan terhadap gejolak internal/eksternal. Dukungan pemerintah terhadap mengembangan pepaya di Kabupaten Sukabumi juga cukup baik. Hal ini terlihat dari adanya program-program yang sifatnya pemberian bantuan-bantuan fasilitas. Dukungan pemerintah ini juga penting khususnya yang berkaitan dengan kebijakan pasar dan harga. Hal ini senada dengan ungkapan Saptana (2010) yang menyatakan bahwa kebijakan pemerintah khususnya ditujukan untuk menghilangkan adanya distorsi pasar dan menekan tingginya harga transaksi.

Demikian pula apabila dilihat dari sisi kemampuan bersaing dengan produk sejenis dari wilayah lain khususnya di Jawa Barat, pepaya Kabupaten Sukabumi mampu bersaing dengan baik. Hanya saja di pasar nasional maupun internasional masih harus ditingkatkan lagi walaupun hingga sekarang komoditas ini telah berhasil dipasarkan ke luar Suka- bumi.

PCR (Private Cost Ratio) adalah indikator dari keunggulan kompetitif, menunjukkan berapa banyak sistem usahatani yang dilakukan dapat membayar input faktor domestiknya namun dapat tetap dalam kondisi kompetitif. Nilai PCR diperoleh dari selisih antara penerimaan kotor dan biaya input tradabel yang semuanya didasarkan pada harga-harga finansial yang berlaku (Pearson et al, 2004).

Berdasarkan hasil analisis pada penelitian ini dapat dilihat bahwa pepaya memiliki nilai kurang dari 1 yaitu 0,21. Hal ini mengandung makna untuk mendapatkan 1 unit nilai tambah usahatani pada ketiga belas komoditas tersebut diperlukan tambahan biaya faktor domestik sebesar nilai PCR unit dalam nilai privat yaitu 0,21 . Dengan demikian pepaya tersebut efisien secara finansial atau memiliki daya saing pada saat ada kebijakan pemerintah.

Keunggulan komparatif suatu komoditas dapat diukur dengan DRCR (Domestic Resources Cost Ratio). DRCR mengukur berapa banyaknya sumber-sumber domestik yang harus dikorbankan di dalam memproduksi suatu barang atau jasa. Kriteria DRCR dilihat dari efisien tidaknya produksi barang/ jasa tradable yang tergantung pada daya saingnya di pasar internasional (Pearson et al, 2004).

Hasil analisis menunjukkan bahwa pepaya memiliki keungggulan komparatif dengan nilai DRC $<1$, yaitu 0,23 . Hal ini mengandung makna bahwa usahatani pepaya mampu mem- 


\section{Jurnal Ekonomi Pembangunan, 15 (2), Desember 2014, 128-140}

biayai biaya input faktor domestiknya pada harga sosial. Artinya semakin efisien dan mampu bertahan hidup tanpa bantuan atau intervensi pemerintah serta mempunyai peluang untuk ekspor.

Keunggulan secara komparatif dan kompetitif ini penting karena keunggulan komparatif terkait dengan kemampuan suatu komoditas dalam menghasilkan keuntungan finansial pada pasar yang dihadapi secara riil sedangkan keunggulan kompetitif terkait dengan kemampuan komoditas untuk memperoleh keuntungan ekonomi pada kondisi pasar persaingan sempurna. Di samping itu bahwa untuk mencapai peningkatan produktivitas maka tidak bisa tidak produk yang dihasilkan harus memiliki keunggulan komparatif dan kompetitif. Namun demikian kedua keunggulan tersebut tidak diperoleh begitu saja dengan mudah melainkan harus melalui tahapan proses dan syarat- syarat tertentu untuk mencapainya seperti yang diungkapkan oleh Arifin (2010), yaitu: basis sumberdaya alam, intensif tenaga kerja, intensif kapital, tenaga kerja terampil, intensif teknologi, dan basis kapabilitas teknologi.

Dengan demikian berdasarkan keunggulan komparatif dan kompetitif yang dimiliki pepaya, dapat disimpulkan bahwa pepaya bukanlah merupakan komoditas yang dapat dibudidayakan atau dikembangkan di Kabupaten Sukabumi berdasarkan analisis kesesuaian tempat tumbuhnya saja atau sekedar karena banyaknya pepaya ini diusahakan oleh masyarakat saja. Di samping merupakan basis, pepaya sebagai komoditas unggulan harus dapat menjadi komoditas andalan yang paling menguntungkan untuk diusahakan atau dikembangkan di Kabupaten Sukabumi, memiliki prospek pasar dan mampu untuk meningkatkan pendapatan serta kesejahteraan petani dan keluarga. Pengembangan pepaya sebagai komoditas unggulan memerlukan strategi khusus sehingga dapat memberikan kontribusi yang optimal bagi pembangunan ekonomi. Hasil penelitian Sonobe, et al (2004), menyimpulkan bahwa strategi yang tepat dan kebijakan pengembangan suatu komoditas yang berkelanjutan adalah melalui peningkatan daya saing.

\subsection{Model Pengembangan Pepaya}

Kondisi faktor berpengaruh terhadap pengembangan pepaya. Berdasarkan hasil pengolahan menunjukkan bahwa semakin baik kondisi faktor akan membuat pengembangan pepaya semakin baik. Elemen kondisi faktor pada penelitian ini meliputi tenaga kerja dan ketersediaan sumberdaya lokal. Bila dilihat dari sisi tenaga kerja, hasil penelitian menunjukkan bahwa jumlah tenaga kerja usahatani pepaya cukup banyak bila dikonversi dalam jumlah hari orang kerja yang didukung dengan ketersediaan tenaga kerja terampil khususnya dalam kegiatan budidaya hingga pascapanen (tidak termasuk pengolahan). Kondisi ini wajar mengingat lamanya pengalaman berusahatani para petani pepaya yang cukup lama hingga puluhan tahun di mana terdapat $49 \%$ petani pepaya berpengalaman usaha tani di atas 10 tahun, bahkan usaha tani pepaya ini bagi sebagian besar dari mereka merupakan usaha turun temurun. Namun keterampilan petani masih harus ditingkatkan lagi agar dapat mengembangkan pepaya yang berdayasaing.

Sementara berdasarkan ketersediaan sumberdaya lokal menunjukkan bahwa kondisi lahan sesuai dengan syarat tumbuh yang diharapkan oleh pepaya, terbukti bahwa pepaya yang dikembangkan dapat tumbuh dengan baik. Demikian pula dalam hal ketersediaan bibit secara lokal, di mana selama ini sebagian besar petani dapat menyediakan bibit secara mandiri walaupun tidak semuanya. Namun secara keseluruhan ketersediaan sumberdaya lokal yang menunjang pengembangan pepaya di Kabupaten Sukabumi dipandang baik berdasar hasil kajian di lapangan. Selain itu infrastruktur seperti jalan dan sarana prasarana yang dibutuhkan untuk mendukung usahatani pepaya dipandang cukup dari sisi kualitas maupun kuantitasnya walaupun belum dapat dikatakan baik. Infrastruktur penting untuk pertumbuhan sektor pertanian dan dampaknya bagi kemajuan pertanian akan terlihat jelas. Berdasarkan hal tersebut, maka peningkatan infrastruktur harus menjadi prioritas.

Berdasarkan kecukupan modal, hasil penelitian menunjukkan bahwa masih banyak petani yang belum mampu secara mandiri dan 


\section{Jurnal Ekonomi Pembangunan, 15 (2), Desember 2014, 128-140}

masih merasa kesulitan akses modal sehingga memerlukan bantuan pihak ketiga dalam rangka penyediaan modal. Akses terhadap permodalan ini dapat lebih mudah apabila petani dapat melakukan perbaikan manajemen usahatani sehingga memenuhi syarat untuk mengakses modal khususnya dari pihak perbankan.

Kondisi permintaan berpengaruh terhadap pengembangan pepaya di mana kondisi permintaan berpengaruh terhadap pengembangan pepaya. Dengan demikian semakin tinggi kondisi permintaan akan membuat pengembangan pepaya menjadi lebih baik. Kondisi permintaan berdasarkan data di lapangan menunjukkan bahwa kemampuan petani dalam memasarkan produknya masih rendah dan petani masih mengandalkan pihak lain seperti tengkulak dan key person. Oleh karena itu untuk membantu petani memasarkan produknya diperlukan penyediaan informasi pasar dan jaringan teknologi serta penumbuhan dan pengembangan jalinan kemitraan.

Adapun rantai tataniaga pepaya Kabupaten Sukabumi ada dua macam sebagaimana dapat dilihat pada Gambar 1. Namun hal ini tidak menjadikan pepaya hasil usahatani mereka sulit dipasarkan karena kenyataannya permintaan akan pepaya terus meningkat. Hal ini disebabkan karena pepaya yang dihasilkan di Kabupaten Sukabumi di antaranya merupakan pepaya lokal dengan nama Bintani yang memiliki keunggulan dari sisi rasanya yang manis dan bentuknya yang khas tidak beraturan. Permintaan juga semakin meningkat seiring dengan adanya permintaan produk untuk kebutuhan industri.
Rantai tataniaga (1) telah berlangsung lama hingga sekarang dengan sistem berlangganan sedangkan rantai tataniaga (2) telah berjalan tiga tahun lebih. Pada rantai tataniaga (1), secara rutin pedagang pengumpul mengumpulkan pepaya di petani kemudian dikirim ke "bandar" atau pedagang besar yang berdomisili di Jakarta setelah itu oleh bandar tersebut pepaya didistribusikan ke berbagai daerah seperti Bogor, Tangerang, Bekasi dan Cianjur. Pepaya tidak hanya disalurkan ke pasar induk, tetapi juga dipasarkan ke Taman Safari untuk memenuhi kebutuhan pakan hewan jenis tertentu di sana.

Industri pendukung dan terkait terhadap pengembangan komoditas unggulan berpengaruh terhadap pengembangan komoditas unggulan. Artinya semakin tersedia industri pendukung dan terkait akan membuat pengembangan komoditas unggulan makin baik. Pada elemen industri pendukung dan terkait, indikator yang diamati adalah ada tidaknya kelembagaan petani, keuangan, penyuluhan dan pasar. Hasil penelitian ini menunjukkan bahwa semua petani telah tergabung dalam kelompok tani dan hampir sebagian besar merasakan kedekatan dan manfaatnya bergabung dalam kelompok tani. Peran kelompok tani penting dalam meningkatkan produktivitas usahatani. Hal ini telah dibuktikan oleh kajian yang dilakukan Nuryanti, Sri dan Dewa K.S. Swastika (2011) yang menyimpulkan bahwa kelompok tani sangat berperan dalam mengoptimalkan peran kelompok sebagai pelaku alih teknologi dan inovasi. Kemudian diperkuat oleh hasil penelitian Kuma, et al (2013), yang menyimpulkan bahwa sekolah lapang dan kelompok tani memiliki

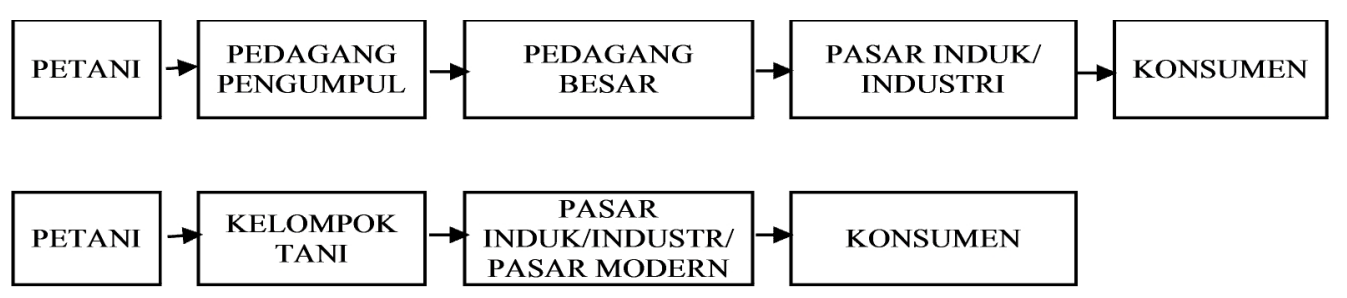

Sumber: Data primer (2014)

Gambar 1. Rantai Tataniaga Pepaya di Kabupaten Sukabumi 


\section{Jurnal Ekonomi Pembangunan, 15 (2), Desember 2014, 128-140}

peran dalam perubahan sikap dan pengetahuan petani.

Kelembagaan keuangan ada tetapi akses terhadap keuangan dirasa masih sulit oleh sebagian besar petani. Kelembagaan yang ada di antaranya adalah perbankan, LKMA dan koperasi. Kelembagaan penyuluh di semua kecamatan yang menjadi setra produksi pepaya tersedia yaitu BP3K (Badan Penyuluhan Perikanan dan Kehutanan). Keberadaan lembaga penyuluhan ini dirasakan manfaatnya oleh petani walaupun sebagian petani ada yang merasa kurang dari sisi layanan karena luasnya wilayah binaan sementara ketersediaan SDM penyuluh masih sangat terbatas. Indikator selanjutnya dalam elemen ini yang dikaji adalah keberadaan dan kedekatan petani dengan lembaga pemasaran. Lembaga pemasaran terdekat cukup banyak baik berupa pasar tradisional maupun modern dan sebagian besar petani merasa dekat karena sudah berlangganan lama, walaupun masih ada petani yang merasa belum mendapatkan manfaat dari keberadaan pasar tersebut karena produk biasanya dijemput langsung oleh tengkulak.

Terakhir adalah persaingan, struktur dan strategi perusahaan terhadap pengembangan komoditas unggulan dengan hasil analisis berpengaruh terhadap pengembangan komoditas unggulan. Artinya semakin tinggi persaingan, struktur dan strategi perusahaan akan membuat pengembangan pepaya menjadi lebih baik. Faktor ini terdiri dari dukungan investasi bagi petani dan kebijakan pemerintah yang berkaitan dengan usahatani seperti: pajak, subsidi dan harga. Hasil penelitian menunjukkan bahwa dukungan investasi dinilai cukup, fasilitasi pemerintah juga sudah ada namun belum optimal. Bila dilihat dari elemen persaingan, pepaya di Kabupaten Sukabumi mempunyai pesaing berupa pepaya dari luar Sukabumi. Namun demikian kualitas pepaya yang dihasilkan Kabupaten Sukabumi tidak kalah sehingga bila dilihat dari rasa bahkan memiliki kelebihan berupa bentuknya yang khas dibandingkan dengan jenis lainnya. Hasil review Craigg E. Amstrong \& Katsuhiko Shimozu (2007), nilai dan keberlanjutan sumberdaya bukan hanya ditentukan oleh kondisi eksternal tetapi juga berdasarkan preferensi konsumen terhadap nilai sumberdaya tersebut. Salah satu sumberdaya yang dimiliki petani pepaya responden adalah berupa merek "Bintani" dengan segala karakteristik khasnya. Kemudian, agar pepaya ini tetap dapat bertahan dalam persaingan maka strategi yang dibangun di antaranya adalah melalui kemitraan, baik dalam hal penyediaan modal dan investasi maupun dalam hal produksi dan pemasaran. Di samping itu, agar berdayasaing, peningkatan produktivitas pepaya juga dapat dilakukan dengan menerapkan teknologi dan melaksanakan pengkajian teknologi budidaya spesifik lokasi.

Berdasarkan hasil analisis tersebut di atas maka model pengembangan pepaya hendaknya diarahkan pada peningkatan kesejahteraan masyarakat khususnya petani. Untuk itu perlu dilakukan dengan memperhatikan faktorfaktor yang dapat mempengaruhi pengembangannya dengan melibatkan pemberdayaan masyarakat dan seluruh kekuatan ekonomi, terutama pengusaha kecil, menengah, dan koperasi. Pemberdayaan dapat dilakukan dengan meningkatkan keterampilan tenaga kerja dalam berusahatani pepaya, optimalisasi pemanfaatan sumberdaya lokal, penguatan dan kemudahan akses terhadap modal dan kelembagaan terkait (lembaga keuangan, lembaga petani, lembaga penyuluhan, lembaga pemasaran), peningkatan dan perbaikan infrastruktur, pengembangkan pepaya yang bertumpu pada mekanisme pasar yang berkeadilan dan berkelanjutan.

Berdasarkan keadaan yang ditemukan di lapangan, maka dalam mengembangkan pepaya sebagai komoditas unggulan lokal Kabupaten Sukabumi hendaknya memperhatikan faktor-faktor yang mempengaruhinya. Data hasil penelitian menunjukkan bahwa keempat faktor Diamond Porter's berpengaruh secara signifikan terhadap pengembangan pepaya di Kabupaten Sukabumi. Setelah diketahui faktor-faktor yang mempengaruhi pengembangan komoditas unggulan lokal ini kemudian dirancanglah suatu model pengembangannya berdasarkan hasil analisis SEM. Model pengembangan dari penerapan konsep Porter's Diamond untuk usahatani pepaya di Kabupaten Sukabumi dapat dilihat pada gambar 2 . 


\section{Jurnal Ekonomi Pembangunan, 15 (2), Desember 2014, 128-140}

Berdasarkan gambar 2, ada tiga hal yang dikemukakan dari model pengembangan pepaya sebagai komoditas unggulan lokal, yaitu: (1) komoditas ungulan lokal dapat berkembang baik apabila memperhatikan faktor-faktor yang mempengaruhinya, (2) faktor yang mempengaruhi pengembangan komoditas unggulan dan model pengembangannya kemunkinan akan berbeda untuk setiap daerah/wilayah (tergantung pada karakteristik dan potensi sumberdaya lokal yang dimiliki), dan (3) pengembangan komoditas unggulan lokal diukur dari segi laba yang diperoleh (profitabilitas), banyaknya penjualan setiap musim panen (pasar), produksi per hektar (produktivitas) dan frekuensi kegiatan penyuluhan (pembelajaran).

Model pengembangan pepaya sebagai komoditas unggulan lokal Kabupaten Sukabumi hendaknya diarahkan pada peningkatan kesejahteraan masyarakat khususnya petani.
Untuk itu perlu dilakukan dengan memperhatikan faktor-faktor yang dapat mempengaruhi pengembangannya dengan melibatkan pemberdayaan masyarakat dan seluruh kekuatan ekonomi, terutama pengusaha kecil, menengah dan koperasi. Berdasarkan kelemahan yang ditemukan di lapangan, pengembangan pepaya di Kabupaten Sukabumi akan berhasil dan berdaya saing apabila memperhatikan:

(1) Aspek tenaga kerja baik dari sisi kualitas maupun kuantitas, (2) Ketersediaan sumberdaya lokal yang dapat dimanfaatkan dalam rangka menunjang pengembangan komoditas unggulan, (3) Tersedianya modal yang mencukupi baik secara mandiri maupun melalui akses dana ke pihak ketiga, (4) Jumlah penjualan yang dapat ditargetkan dan kualitas produk yang harus dicapai

Berdasarkan hal tersebut maka pemberdayaan dapat dilakukan dengan meningkatkan keterampilan tenaga kerja dalam berusahatani

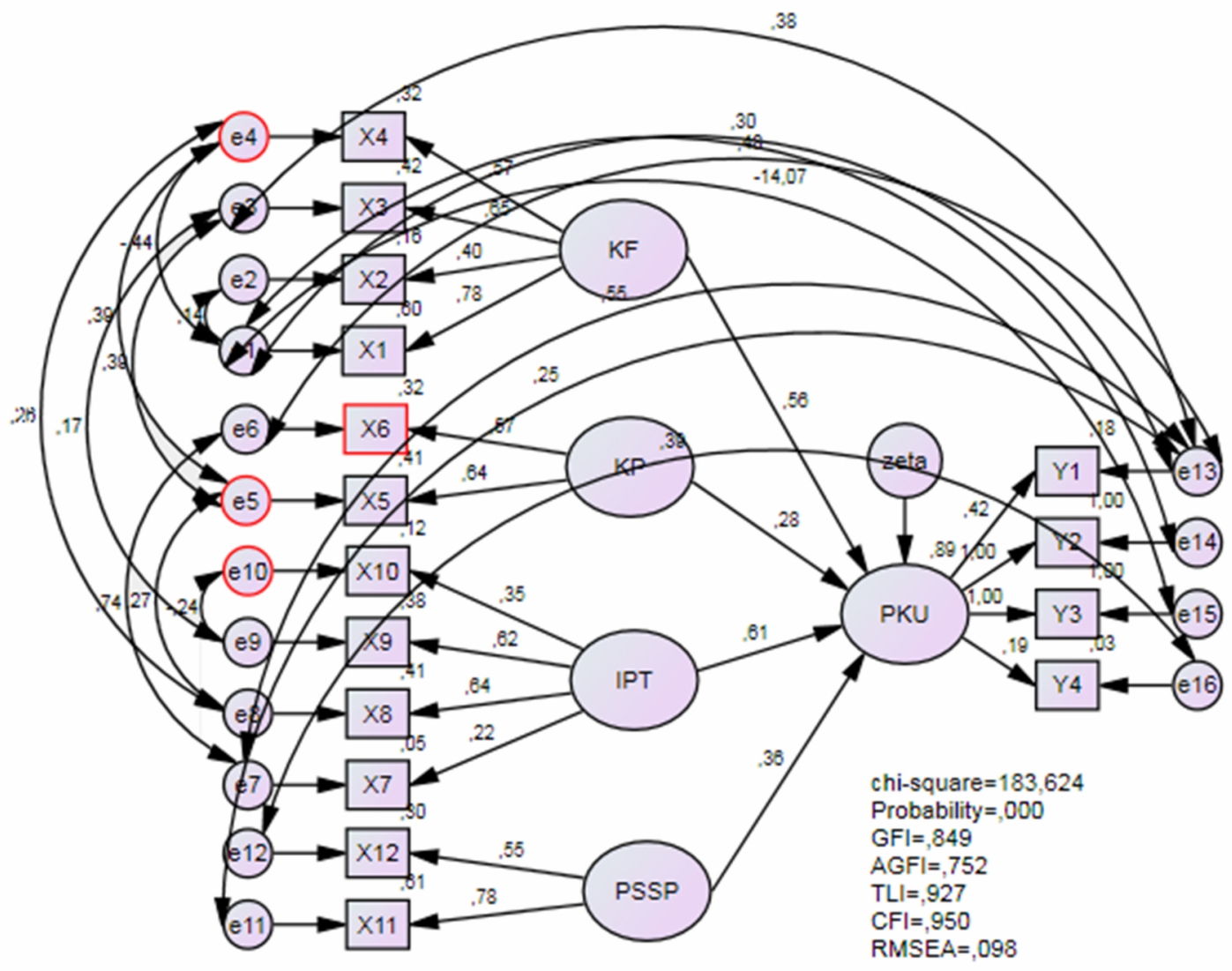

Sumber: Data primer dan sekunder, diolah. 2014

Gambar 2. Model pengembangan pepaya sebagai komoditas unggulan lokal kabupaten Sukabumi 
pepaya, optimalisasi pemanfaatan sumberdaya lokal, penguatan dan kemudahan akses terhadap modal dan kelembagaan terkait (lembaga keuangan, lembaga petani, lembaga penyuluhan, lembaga pemasaran), peningkatan dan perbaikan infrastruktur, pengembangkan pepaya yang bertumpu pada mekanisme pasar yang berkeadilan dan berkelanjutan.

\section{Simpulan}

(1) Penilaian keunggulan komparatif dan kompetitif suatu komoditas dapat dilakukan dengan mengkombinasikan atau menggabungkan analisis LQ, kriteria unggul dan analisis daya saing. (2) Konsep daya saing pada Diamond Porter's ternyata dapat diterapkan di tingkat usahatani. (3) Pengembangan pepaya sebagai komoditas unggulan lokal di Kabupaten Sukabumi dapat memaksimalkan peningkatan nilai tambah bagi petani dan masyarakat apabila memperhatikan faktor-faktor yang mempengaruhinya.

Saran yang dapat diberikan berdasarkan hasil pembahasan di atas adalah bahwa: (1) pemerintah hendaknya dapat menetapkan kebijakan pembangunan pertanian secara terfokus melalui pengembangan komoditas unggulan, (2) pemerintah dalam menentukan komoditas unggulan yang akan dikembangkan hendaknya tidak hanya berdasarkan karena tren atau adanya program semata dan luasnya usahatani tersebut dilakukan, agar komoditas yang terpilih benar-benar unggul dan diharapkan dapat meningkatkan nilai tambah bagi petani serta daya ungkit daerah, (3) pemerintah hendaknya memperhatikan faktor-faktor apa saja yang dapat mempengaruhi pengembangan komoditas unggulan dan mengupayakan perbaikan-perbaikan terhadap kelemahan yang ditemukan.

\section{Daftar Pustaka}

Amalia, Fitri. 2014. Determination of regional economy leading sectors in Indonesia. Jurnal Ekonomi Pembangunan. Volume 15, No. 1, Juni 2014. hlm 19-26.

Agus, Moch Krisno Budiyanto. 2010. Model pengembangan ketahanan pangan berbasis pisang melalui revitalisasi nilai kearifan lokal. Jurnal Teknik Industri, Vol. 11. No. 2, Agustus 2010.

Arifin, Bustanul. 2010. Model-model pembangunan perdesaan dan performance indikator pembangunan perdesaan. (Makalah yang disajikan dalam seminar pembangunan perdesaan dengan integrasi pendekatan wilayah dan kegiatan sektoral) Badan Perencanaan Pembangunan Nasional. Kementrian Perencanaan Pembangunan Nasional. Republik Indonesia

Goerge, Galanos dan Giannis Manasis. (2010). Analysis of competitiveness of greek's olive oil sector using porter's diamond model. Research Journal of International Studies-Issues (16 September 2010), pg 33-46. Melalui www.eurojournals.com/ rjis-16-04.pdf (12/09/12).

Hendayana. (2003). Aplikasi Metode Location Quotient (LQ) dalam penentuan komoditas unggulan nasional. Informatika Pertanian. Vol 12. Desember 2003. hlm 1-21.

K, Amar Zakaria, Wahyuning K. Sejati dan Reni Kustiari. 2010. Analisis daya saing komoditas kedelai menurut agroekosistem: kasus di tiga provinsi di indonesia. Jurnal agro ekonomi. Vol. 8. No. 1. Mei 2010, hlm 21 - 37. Pusat Analisis Sosial Ekonomi dan Kebijakan Pertanian. Badan Penelitian dan Pengembangan Pertanian. Kementrian Pertanian.

Kuma Berhanu, Abebe, Chindi, Shenkut Ayele, Gebremedhin Woldegiorgis, Yohanner Lemma and Shiferaw Tafesse. 2013. Role of farmer field school and farmer research group in bringing attitudinal and knowledge change: the case of integrated potato disease and nutrient management in ethiopia. Asian Journal of Rural Development. Vol. 3. Issue 1. PP. 1-13.

Mukhlis Supfri. 2012. Development of competitiveness of farm commodity at selayar regency south sulawesi province. IAMURE: International Journal of Business and Management. Vol 2. No. 1. Pg: 59-74. 


\section{Jurnal Ekonomi Pembangunan, 15 (2), Desember 2014, 128-140}

Nazir, M. 2005. Metode penelitian. Bogor: Penerbit Ghalia Indonesia.

Nuryanti, Sri dan Dewa K.S. Swastika. 2011. Peran kelompoktani dalam penerapan teknologi pertanian. pusat sosial ekonomi dan kebijakan pertanian. Forum Penelitian Agro Ekonomi. Volume 29. No. 2. Desember 2011. Hlm: 115-128. http:// pse.litbang.pertanian.go.id/ind/ pdffiles/FAE29-2d.pdf.

Pearson Scott, Carl Gotsch and Sjaiful Bahri. 2004. Aplications of the policy analysis matrix in indonesian agriculture. Yayasan Obor Indonesia. Jakarta.

Porter, Michael E. 1998. The competitive advantage of nations. with a new introduction/Michael E. Porter. The Free Press. A Division of Simon \& Schuster Inc. 1230 Avenue of The Americas. New York, NY 10020.

Saptana. 2010. Tinjauan konseptual mikromakro daya saing dan strategi pembangunan Pertanian. Forum penelitian agroekonomi. Pusat analisis sosial ekonomi dan kebijakan pertanian. Badan Penelitian dan Pengembangan Pertanian. Kementrian Pertanian. FAE, Vol. 28 No. 1, Juli 2010. hlm $1-18$
Sonobe, Tetsushi; Dinghuan $\mathrm{Hu}$ and Keijiro Otsuka. 2004. From inferior to superior products: an inquiry into the wenzhou model of industrial development in China. ELSEIVER, Journal of Comparative Economics 32.

Sukmawani Reny, Maman Haeruman K, Lies Sulistiyowati, and Tomy Perdana. 2014. Determining agricultural superior commodity in the district of Sukabumi through a combination method of $\mathrm{LQ}$, description scoring, and competitive analysis. Research Journal of Agriculture and Environmental Management. Vol. 3(11), November 2014. pp. 599-604.

Sulaeman, Suhendar. 2012. Model pengembangan agribisnis komoditi lidah buaya (Aloevera). Jurnal Agribisnis. hlm 1-17.

Widiatnaka, Zulfikar, Syaiful Anwar dan Wiwin Ambarwulan. 2013. Perencanaan spasial pemanfaatan lahan untuk komoditas perkebunan rakyat di kabupaten Pidie Jaya, Provinsi Nangroe Aceh Darussalam. Jurnal Ilmiah Geomatika. Vol 19. No. 1. Agustus 2013. hlm 40-49

Winarno, Budi. 2003. Globisaalsi, Kemiskinan, dan Ketimpangan dalam distribusi pendapatan: kasus indonesia. EKUITAS, Jurnal Ekonomi dan Keuangan, Vol.8. 